\title{
Occurrence of Multi-Resistant Staphylococcus aureus in Artisan Goat Coalho Cheese in Northeastern Brazil
}

\author{
Breno Bezerra Aragão ${ }^{1}$, Sabrina Cândido Trajano ${ }^{2}$, Renato Amorim da Silva ${ }_{\odot}^{3}$, \\ Bruno Pajeú e Silva ${ }^{1}$, Rodolfo de Moraes Peixoto ${ }^{4}$ \& Rinaldo Aparecido Mota ${ }^{1}$
}

\begin{abstract}
Background: The artisanal goat coalho cheese is one of the products obtained that stand out in the dairy goat farming of the Northeast of Brazil. Despite its importance, goat cheese is often made under inadequate hygienic-sanitary conditions and usually uses raw goat's milk, increasing the risk of product contamination. Among the pathogens carried by goat coalho cheese, Staphylococcus aureus stands out, being responsible for cases of food poisoning and persistent infections that are difficult to treat. This study aimed to evaluate the contamination, genotypic and phenotypic resistance of Staphylococcus aureus isolated from artisanal coalho cheese made with goat milk produced in the Northeast region of Brazil.

Materials, Methods \& Results: This study analyzed only artisanal coalho cheeses made with raw goat's milk and purchased directly from farms. Twelve samples of artisanal coalho cheeses made with raw goat's milk were collected (1 sample per property) in 8 municipalities in the state of Pernambuco, Northeast region of Brazil. For microbiological analysis of enumeration of Colony Forming Units (CFU/g) of Staphylococcus spp. the methodology recommended by the International Organization for Standardization (2019) and recognized by the Ministry of Agriculture, Livestock and Supply was used. After enumeration, 5 colonies were selected per enumerated plate, a total of 180 Staphylococcus spp. was obtained. These were subjected to thermal extraction of genetic material to search for the nuc gene by Polymerase Chain Reaction, the isolates carrying the nuc gene were subjected to genotypic and phenotypic evaluation of antimicrobial resistance. After the phenotypic analysis, the Multiple Antimicrobial Resistance Index was evaluated. In all samples, Staphylococcus spp. and were considered unfit for consumption, with the lowest count being $9.4 \times 10^{3} \mathrm{CFU} / \mathrm{g}$ and the highest $6.4 \times 10^{6} \mathrm{CFU} / \mathrm{g}$. Of the 180 isolates, $28.34 \%$ (51/180) were positive for the detection of the nuc gene. All resistance genes except mecA, mec $C$, and norB were detected. Of the 51 S. aureus isolates, $31.37 \%$ (16/51) were considered multi-resistant and presented a Multiple Antimicrobial Resistance Index above 0.2.

Discussion: After microbiological analysis it was found that all samples of coalho cheese were out of standards and unfit for human consumption in accordance with Ordinance no 146/1996 of the Ministry of Agriculture, Livestock and Supply of Brazil. Furthermore, the contamination of goat coalho cheeses is a risk to public health. During sample collection were found inadequate hygiene conditions in the environment used for cheese production. The presence of Staphylococcus aureus can be attributed to hygienic-sanitary failures in cheese production. From a health point of view, it is even more alarming when it comes to $S$. aureus carrying resistance genes. Although the $51 \mathrm{~S}$. aureus isolates did not carry the mecA, mecC, norB genes and did not show phenotypic resistance to cefoxitin and oxacillin, all other genes were detected, indicating the circulation of $S$. aureus carrying the tet $(L)$ genes, $\operatorname{tet}(M)$, tet-38, msrA, norA, and norC, which so far had not been reported in the production chain of goat coalho cheese in Brazil. Furthermore, the evaluation of the Multiple Antimicrobial Resistance Index identified the occurrence of multiple resistance to antimicrobials in 31.37\% (16/51) of S. aureus at high risk to human health. The results obtained are quite worrying and serve as a warning to the scientific community and the Food Safety and Hygiene Inspection Services.
\end{abstract}

Keywords: goat cheese, contamination, resistance, one health. 


\section{INTRODUCTION}

Dairy goat farming plays a highly important socio-economic role in the Northeast region of Brazil, as goats are adapted to the Cantiga biome which is unique in the world. The main product of goat's milk is the goat coalho cheese, which is a typical example of cheese from the Northeast region of Brazil, produced with raw goat's milk, which is recognized as a culturally and economically important product. Its production is handcrafted and the manufacturing technology comes from knowledge passed from generation to generation, following a family tradition. Despite this, the lack of sanitation and production in inadequate environments increases the risk of contamination [21].

Among the contaminating pathogens of goat milk and artisan coalho cheese made with goat milk, Staphylococcus aureus stands out, as it is considered the most frequent bacterial species. In addition, S. aureus contaminates utensils used for cheese manufacturing, remaining for several days, favouring intercellular interactions to exchange genetic material horizontally resulting in antimicrobial-resistant bacteria, causing losses to the dairy industry, and a potential risk to public health [12].

Despite the importance of artisanal coalho cheese made with goat milk, little information is available on Staphylococcus spp. and the profile of multiresistant bacteria to antimicrobials. This study aimed to evaluate the contamination, genotypic and phenotypic resistance of Staphylococcus aureus isolated from artisanal coalho cheese made with goat milk produced in the Northeast region of Brazil.

\section{MATERIALS AND METHODS}

\section{Goat coalho cheese samples}

In the period between March and December 2019, 12 samples of artisanal coalho cheese made with goat's milk were collected (1 sample per property) in 8 municipalities in the state of Pernambuco, Northeast region of Brazil. One sample was collected in municipality $A ; 2$ in municipality $B ; 1$ in municipality $C ; 1$ in municipality $\mathrm{D} ; 4$ in municipality $\mathrm{E} ; 1$ in municipality $\mathrm{F}$; 1 in municipality $\mathrm{G}$, and 1 in municipality $\mathrm{H}$ (Figure 1 ).

The purchased cheese samples weighed approximately $500 \mathrm{~g}$, and after collection, were stored in sterilized bags with zip lock ${ }^{1}$, identified and packed in isothermal boxes with recyclable ice at a temperature of $\left(4\right.$ to $\left.8^{\circ} \mathrm{C}\right)$ and transported to the laboratory for microbiological and molecular analysis.

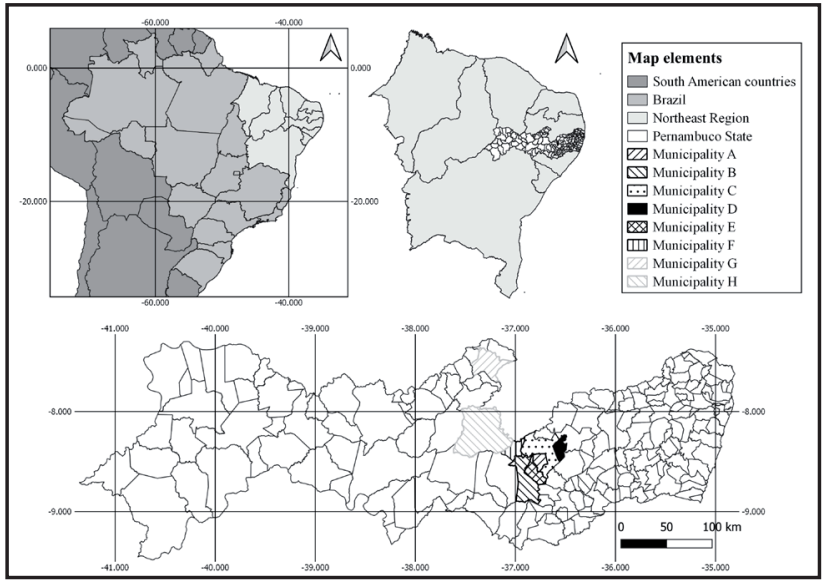

Figure 1. Distribution of samples by sampled municipalities in the state of Pernambuco, Brazil.

\section{Enumeration of Staphylococcus}

Enumeration of Staphylococcus spp. was performed according to the methodology recommended by the International Organization for Standardization [8] with adaptations. Initially, $25 \mathrm{~g}$ of different parts of each cheese sample were weighed, then transferred to sterile ziplock ${ }^{\circledR}$ bags containing $225 \mathrm{~mL}$ of sterile saline solution at $0.85 \%$. Then, they were homogenized for 60 $\mathrm{s}$ in Stomacher blender ${ }^{2}$, and from this solution, serial dilutions were made up to 10-6. From these dilutions, $0.1 \mathrm{~mL}$ aliquots were taken and seeded in triplicate on Baird-Parker agar ${ }^{3}$ enriched with egg yolk emulsion and potassium tellurite ${ }^{4}$. Plates were incubated at $35-$ $37^{\circ} \mathrm{C}$ for $48 \mathrm{~h}$ [8].

After bacterial growth, colonies were counted in plates containing between 20 and 200 colonies and the results were expressed in Colony Forming Unit (CFU/g) [8]. Then, 5 characteristic colonies of Staphylococcus spp. were selected from each of the enumerated plates. A total of 180 colonies of Staphylococcus spp. were selected from the obtained samples.

\section{Identification of Staphylococcus aureus}

For the molecular identification of $S$. aureus, DNA extraction was employed in the 180 colonies of Staphylococcus spp. For the extraction of genetic material, the methodology proposed by Fan et al. [5] was used. The DNA obtained was quantified and analysed for its purity degree in a spectrophotometer with absorbance readings at $260 \mathrm{~nm}$.

For molecular confirmation of the $S$. aureus species, amplification of the specific region of the nuc gene was performed according to the technique described by Brakstad et al. [1], with adaptations in 
the reagent concentrations. The reactions were adapted to a final volume of $12.5 \mu \mathrm{L}$ per microtube, containing $100 \mathrm{ng}$ template DNA, primers (10 pmol each) as shown in Table 1, using $6.25 \mu \mathrm{L}$ of Go-TaqGreen Master Mix ${ }^{5}$ (Table 1).

Then, $10 \mu \mathrm{L}$ of the reaction were subjected to electrophoresis for $40 \mathrm{~min}$ at $100 \mathrm{~V}$ in a $1.5 \%$ agarose gel stained with BlueGreen, visualized and photographed in a photo documenter under ultraviolet light. As a positive control for detection of the nuc gene, the strain Staphylococcus aureus N315 was used. As a negative control, DNA-Free Water ${ }^{6}$ was used.

Search for resistance genes in $\mathrm{S}$. aureus

For the detection of resistance genes (blaZ, mecA, mecC, tet $(L), \operatorname{tet}(M)$, norA, norB and nor $C$, tet$38, m s r A$ ) the conventional polymerase chain reaction (PCR) technique was employed, using the methodology of the references (Table 1), with adaptations in the reagent concentrations. The reactions were formatted to a final volume of $12.5 \mu \mathrm{L}$ per microtube, containing 100 ng template DNA, primers (10 pmol each), using 6.25 $\mu \mathrm{L}$ of Go-TaqGreen Master Mix ${ }^{5}$. Then, $10 \mu \mathrm{L}$ of the reaction were subjected to electrophoresis for $40 \mathrm{~min}$ at $100 \mathrm{~V}$ in a $1.5 \%$ agarose gel stained with BlueGreen, visualized and photographed in a photo documenter under ultraviolet light. As a positive control, were used reference strains to detect specific regions. As a negative control, DNA-Free Water ${ }^{6}$ was used.

Analysis of the phenotypic resistance profile

To assess the antimicrobial resistance profile, the disc diffusion technique on Mueller-Hinton agar7 was used according to the Clinical and Laboratory Standards Institute methodology [4]. To perform the test were used discs impregnated with Penicillin G (10UI), Cefoxitin $(30 \mu \mathrm{g})$, Oxacillin $(1 \mu \mathrm{g})$, Tetracycline $(30 \mu \mathrm{g})$, Norfloxacin $(10 \mu \mathrm{g})$, and Erythromycin $(15 \mu \mathrm{g}) 8$. The zone of inhibition was interpreted after $24 \mathrm{~h}$ of incubation [4].

Calculation of Multiple antibiotic resistance (MAR) index

To calculate the multiple antimicrobial resistance (MAR) index, the Krumperman [10] methodology was used.

\section{Statistical analysis}

The results of qualitative diagnostic tests (genotypic and phenotypic resistance) were expressed in their absolute and relative frequencies [6].

Table 1. Genes, oligonucleotide sequences and size of amplified fragments.

\begin{tabular}{|c|c|c|c|}
\hline Gene & Sequence $\left(5^{\prime}-3^{\prime}\right)$ & Fragment Size $(\mathrm{pb})$ & References \\
\hline nис & $\begin{array}{c}\text { F- GCGATTGATGGTGATACGGTI } \\
\text { R- AGCCAAGCCTTGACGAACTAAAGC }\end{array}$ & 270 & [1] \\
\hline blaZ & $\begin{array}{l}\text { F- AAGAGATTTGCCTATGCTTC } \\
\text { R- GCTTGACCACTTTTATCAGC }\end{array}$ & 517 & {$[22]$} \\
\hline mecA & $\begin{array}{l}\text { 2W- TGGTATGTGGAAGTTAGATTGGGAT } \\
\text { 2X-CTAATCTCATATGTGTTCCTGTATTGGC }\end{array}$ & 155 & [16] \\
\hline mecC & $\begin{array}{l}\text { 1A- CATTAAAATCAGAGCGAGGC } \\
\text { 1B- TGGCTGAACCCATTTTTGAT }\end{array}$ & 188 & {$[18]$} \\
\hline $\operatorname{tet}(L)$ & $\begin{array}{l}\text { F- TCGTTAGCGTGCTGTCATTC } \\
\text { R- GTATCCCACCAATGTAGCCG }\end{array}$ & 267 & [17] \\
\hline $\operatorname{tet}(M)$ & $\begin{array}{l}\text { GTG GAC AAA GGT ACA ACG AG } \\
\text { CGG TAA AGT TCG TCA CAC AC }\end{array}$ & 406 & {$[17]$} \\
\hline norA & $\begin{array}{l}\text { F- TGCAATTTCATATGATCAATCCC } \\
\text { R- AGATTGCAATTCATGCTAAATATT }\end{array}$ & 150 & {$[26]$} \\
\hline norB & $\begin{array}{l}\text { F- ATAAGGTAAGATAACTAGCA } \\
\text { R- ATCTCTATTTGCCTCCCTATA }\end{array}$ & 150 & {$[25]$} \\
\hline norC & $\begin{array}{l}\text { F- ATAAATACCTGAAGCAACGCCAAC } \\
\text { R- AAATGGTTCTAAGCGACCAA }\end{array}$ & 200 & {$[25]$} \\
\hline tet-38 & $\begin{array}{l}\text { F- TTCAGTTTGGTTATAGACAA } \\
\text { R- CGTAGAAATAAATCCACCTG }\end{array}$ & 200 & {$[24]$} \\
\hline$m s r A$ & $\begin{array}{l}\text { F- TCCAATCATTGCACAAAATC } \\
\text { R- AATTCCCTCTATTTGGTGGT }\end{array}$ & 890 & {$[14]$} \\
\hline
\end{tabular}


B.B. Aragão, S.C. Trajano, R.A. Silva, et al. 2021. Occurrence of Multi-Resistant Staphylococcus aureus in Artisan Goat Coalho

\section{RESULTS}

In the microbiological analysis of the cheeses, the growth of characteristic colonies of Staphylococcus spp. was observed in $100.0 \%$ of the analysed samples. Regarding the count of CFU/g of Staphylococcus spp., all cheeses were considered unfit for consumption, with the lowest count $\left(9.4 \times 10^{3}\right)$ observed in property 7 in municipality B and the highest $\left(6.4 \times 10^{6}\right)$ in property 12, in municipality H. Of the analysed samples, $91.60 \%$ (11/12) had values equal to or greater than $10^{5} \mathrm{CFU} / \mathrm{g}$ in Baird-Parker agar (Table 2).
Of the 180 Staphylococcus spp. submitted to PCR to detect the nuc gene, $28.34 \%$ (51/180) were positive. Regarding the contamination of cheeses by property, $66.67 \%(8 / 12)$ of the samples were contaminated by $S$. aureus (Table 3 ).

The genotypic and phenotypic resistance data are shown in Figure 2. There was no detection of the mecA, mecC and norB resistance genes in the $51 \mathrm{~S}$. aureus isolates.

Of the $51 \mathrm{~S}$. aureus isolates, $31.37 \%(16 / 51)$ were considered multi-resistant and presented a MAR index above 0.2 (Table 4).

Table 2. CFU/g counts in Baird-Parker agar of characteristic colonies of Staphylococcus spp. in different municipalities and properties.

\begin{tabular}{ccc}
\hline Municipalities & Properties & CFU/g \\
\hline Municipality A & 1 & $1.22 \times 10^{5}$ \\
\hline Municipality B & 2 & $1.1 \times 10^{6}$ \\
& 3 & $1.57 \times 10^{5}$ \\
\hline Municipality C & 4 & $1.23 \times 10^{5}$ \\
\hline Municipality D & 5 & $1.06 \times 10^{5}$ \\
\hline & 6 & $1.03 \times 10^{5}$ \\
Municipality E & 7 & $9.4 \times 10^{3}$ \\
& 8 & $1.53 \times 10^{6}$ \\
\hline Municipality F & 9 & $6.2 \times 10^{5}$ \\
\hline Municipality G & 10 & $2.9 \times 10^{5}$ \\
\hline Municipality H & 11 & $6.2 \times 10^{5}$ \\
\hline
\end{tabular}

Table 3. Absolute and relative frequencies of properties with cheese samples positive for Staphylococcus aureus.

\begin{tabular}{|c|c|c|c|}
\hline \multirow{3}{*}{ Properties } & \multirow{3}{*}{ Number of isolates from Staphylococcus spp. } & \multicolumn{2}{|c|}{ nuc gene } \\
\hline & & \multicolumn{2}{|c|}{ Positive } \\
\hline & & F.A. & F.R. $(\%)$ \\
\hline Property 1 & 15 & 0 & 0.0 \\
\hline Property 2 & 15 & 1 & 6.67 \\
\hline Property 3 & 15 & 2 & 13.34 \\
\hline Property 4 & 15 & 10 & 66.67 \\
\hline Property 5 & 15 & 10 & 66.67 \\
\hline Property 6 & 15 & 0 & 0.0 \\
\hline Property 7 & 15 & 6 & 40.0 \\
\hline Property 8 & 15 & 9 & 60.0 \\
\hline Property 9 & 15 & 1 & 6.67 \\
\hline Property 10 & 15 & 12 & 80.0 \\
\hline Property 11 & 15 & 0 & 0.0 \\
\hline Property 12 & 15 & 0 & 0.0 \\
\hline Total & 180 & 51 & \\
\hline
\end{tabular}


Table 4. Distribution of resistance pattern and multiple antimicrobial resistance (MAR) index of 16 Staphylococcus aureus isolates isolated in goat cheese coalho.

\begin{tabular}{ccc}
\hline Antimicrobial resistance profile & Number of resistant isolates & MAR \\
\hline Pen, Tet, Nor e Eri. & 1 & 0.66 \\
Pen, Tet e Nor & 4 & 0.50 \\
Pen, Nor e Eri & 2 & 0.50 \\
Pen e Tet & 3 & 0.33 \\
Pen e Eri & 4 & 0.33 \\
Nor e Eri & 1 & 0.33 \\
Pen e Nor & 1 & 0.33 \\
\hline Pen= Penicillin G 10 UI; Tet= Tetracycline $30 \mu \mathrm{g}$; Nor= Norfloxacin $10 \mu \mathrm{g} ;$ Eri= Erythromycin $15 \mu \mathrm{g}$.
\end{tabular}

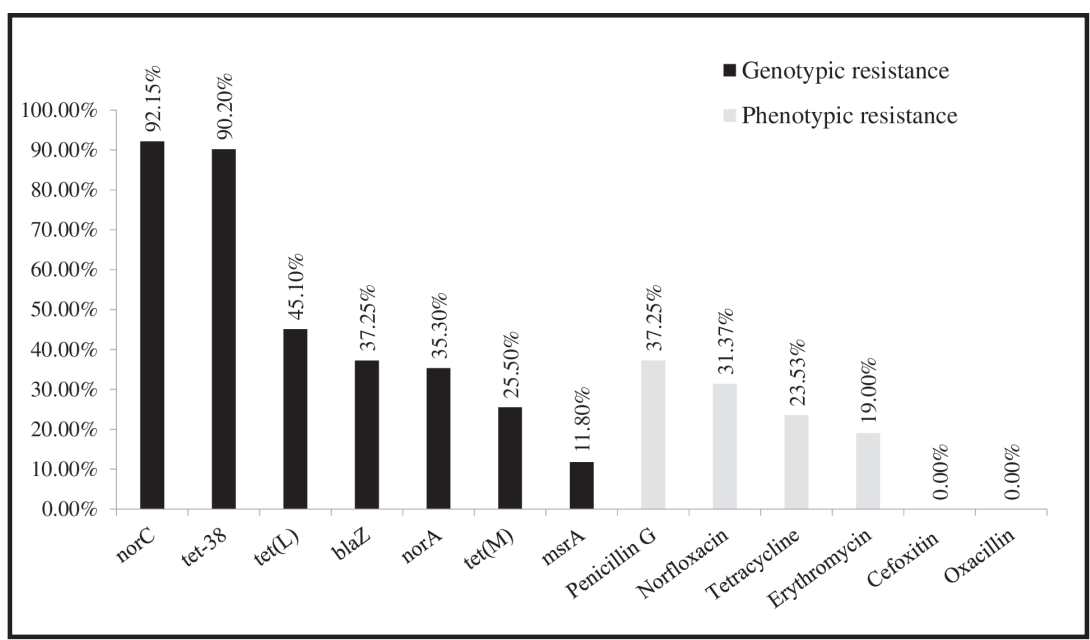

Figure 2. Distribution of genotypic and phenotypic resistance frequencies of Staphylococcus aureus isolated in goat cheese.

\section{DISCUSSION}

The results obtained in the microbiological analysis revealed that all the evaluated samples of coalho cheese were not up for standards and unfit for human consumption per Ordinance No. 146/1996 of the Ministry of Agriculture, Livestock and Supply (MAPA) of Brazil, which recommends $1 \times 10^{3} \mathrm{CFU}$ /g for high moisture cheeses, as goat cheese coalho is classified [2]. In addition to non-compliance with the legislation these cheeses present an imminent risk of poisoning by staphylococcal enterotoxins for their consumers, since they presented values equal to or greater than $10^{5} \mathrm{CFU} / \mathrm{g}$ for Staphylococcus spp. in Baird-Parker agar, being considered at high risk for food poisoning worldwide [9]. Souza et al. [23] in a similar study carried out in another region of Brazil has also detected $17.4 \%$ of $S$. aureus in 160 analysed samples. Contamination of goat coalho cheese is a public health risk. During sample collection, were found inadequate hygiene conditions in the environment used for cheese production.

From a sanitary point of view, the contamination of the analysed cheeses is even more alarming when it comes to $S$. aureus carriers of resistance genes. Although the $51 S$. aureus isolates did not carry the mecA, mec $C$, nor $B$ genes, and did not show phenotypic resistance to cefoxitin and oxacillin, all other genes were detected, indicating the circulation of $S$. aureus carrying the tet $(L)$, tet $(M)$, tet-38, msrA, norA and nor $C$ genes which, so far, had not been reported in the production chain of goat coalho cheese in Brazil.

The occurrence of genotypically and phenotypically resistant $S$. aureus reveals the spread of genetically evolved strains [3]. The abusive use of antimicrobials in veterinary and human medicine, as well as residual antibiotics that are excreted or discharged in nature, probably contribute to the high frequency of antimicrobial-resistant bacteria [11]. In addition, there is the possibility of acquired resistance, 
through mutations in genes (chromosomal mutation), transfer of genes from one microorganism to another by plasmids (conjugation or transformation), transposons (conjugation), integrations, and bacteriophages (transduction) [7].

Selective pressure and the emergence of new resistant strains is a very concerning genetic mechanism and the prevalence detected in this study for the blaZ, tet $(L)$, tet $(M)$, tet-38, norA, and norC genes may become even higher due to the evolvability of $S$. aureus [3]. In addition, the occurrence of $11.8 \%(6 / 51)$ of the $m s r A$ gene in $S$. aureus found in goat cheese is concerning, as this gene is responsible for conferring resistance to the classes of macrolides, lincosamides, and streptogramins, the main drugs used as alternatives in the treatment of glycopeptide-resistant Staphylococcus in humans [20].

Although macrolides, lincosamides, and streptogramins are not used in the treatment of caprine mastitis or other infections in animals [15], 19\% (10/51) of $S$. aureus isolates exhibited phenotypic resistance to erythromycin. Thus, it is suggested that $S$. aureus carriers of the $m s r A$ gene detected in our study are of human origin since, in human medicine, these antimicrobials are of usual prescription as alternative antibiotics in the treatment of persistent staphylococcal infections [27]. In addition to the occurrence of resistance genes, the MAR assessment allowed the identification of multiple resistance to antimicrobials in $31.37 \%(16 / 51)$ of $S$. aureus that presents a high risk to human health [13].

The high rate of genotypic resistance and low phenotypic detection in isolated Staphylococcus aureus may be associated with changes in gene expression triggered by mutations, phages, plasmids, and transposons. Therefore, the multiplicity of factors associated with phenotypic resistance requires careful investigation. The detection of different genetic resistance markers, as well as the study of the regulation of gene expression, allows for a deeper understanding of the real value of their detection in predicting antimicrobial resistance, as recommended by the Clinical and Laboratory Standards Institute [19].

\section{CONCLUSION}

The results obtained in microbiological analyses reveal that all evaluated cheeses were unfit for consumption and serve as a warning to the scientific community and the Food Safety and Hygiene Inspection Services. The detection of multi-antimicrobial resistant $S$. aureus in cheese is a risk to the health of consumers, in addition to causing a negative economic impact on the production chain of this type of cheese, which is highly consumed by residents and tourists. The need for regular monitoring of this production chain to control and minimize $S$. aureus contamination of the cheese is emphasized.

\author{
MANUFACTURERS \\ ${ }^{1}$ Thomas Scientific LLC. Swedesboro, NJ, USA. \\ ${ }^{2}$ Seward Laboratory Systems Inc. Bohemia, NY, USA. \\ ${ }^{3}$ Difco Laboratories Incorporated. Detroit, MI, USA. \\ ${ }^{4}$ HiMedia Leading BioSciences Company. Mumbai, India. \\ ${ }^{5}$ Promega Corporation. Fitchburg, WI, USA. \\ ${ }^{6}$ QIAGEN GmbH. Hilden, Germany. \\ ${ }^{7}$ Merck KGaA. Darmstadt, Germany. \\ ${ }^{8}$ Laborclin Produtos para Laboratórios Ltda. Pinhais PR, Brazil.
}

Acknowledgements. We thank the Fundação de Amparo à Ciência e Tecnologia do Estado de Pernambuco for the scholarship (IBPG-0467-5.05/17).

Declaration of interest. The authors declare no conflicts of interest. Only the authors are responsible for the content and writing of the article.

\section{REFERENCES}

1 Brakstad O.G., Aasbakk K. \& Maeland J.A. 1992. Detection of Staphylococcus aureus by polymerase chain reaction amplification of the nuc gene. Journal of Clinical Microbiology. 30: 1654-1660.

2 BRASIL. Ministério da Agricultura, Pecuária e Abastecimento. Portaria no 146 de 07 de março de 1996. Oficializa os Regulamentos Técnicos de Identidade e Qualidade dos Produtos Lácteos. Brasília: Ministério da Agricultura, Pecuária e Abastecimento, 1996. Available in: < https://www.dourados.ms.gov.br/wp-content/uploads/2016/05/RTIQLeite-Completo-PORTARIA-146_96-ok.pdf >. [Accessed online in June 2021].

3 Chambers H.F. \& Deleo F.R. 2009. Waves of resistance: Staphylococcus aureus in the antibiotic era. Nature Reviews Microbiology. 7: 629-641. 
4 Clinical and Laboratory Standards Institute (CLSI). 2017. Performance Standards for Antimicrobial Susceptibility Testing, 27th ed. Clinical and Laboratory Standards Institute, 950 West Valley Road, Suite 2500, Wayne, Pennsylvania 19087 USA (CLSI supplement M100). (accessed 26 June 2021). Available in: <https://file.qums.ac.ir/repository/mmrc/ clsi\%202017.pdf>. [Accessed online in June 2021].

5 Fan H.H., Kleven S.H. \& Jackwood, M.W. 1995. Application of polymerase chain reaction with arbitrary primers to strain identification of Mycoplasma gallisepticum. Avian Diseases. 39: 729-735.

6 Field A. 2009. Descobrindo a estatística usando o SPSS. 2.ed. Porto Alegre: Artmed, 688 p.

7 Giedraitiene A., Vitkauskiene A., Naginiene R. \& Pavilonis A. 2011. Antibiotic resistance mechanisms of clinically important bacteria. Medicina. 47: 137-146.

8 ISO - International Organization for Standardization. 2019. Microbiology of food and animal feeding stuffs - Horizontal method for the enumeration of coagulase-positive staphylococci (Staphylococcus aureus and other species) - Part 1: Technique using Baird-Parker agar médium. Available in: <https://www.normas.com.br/visualizar/abnt-nbr-nm/11661/ abnt-nbriso6888-1-microbiologia-de-alimentos-para-consumo-humano-e-animal-metodo-horizontal-para-enumeracaode-estafilococos-coagulase-positiva-Staphylococcus-aureus-e-outras-especies-parte-1-tecnica-usando-agar-bairdparker>. [Accessed online in June 2021].

9 Johler S., Giannini P., Jermini M., Hummerjohann J., Baumgartner A. \& Stephan R. 2015. Further Evidence for Staphylococcal Food Poisoning Outbreaks Caused by egc-Encoded Enterotoxins. Toxins. 7: 997-1004.

10 Krumperman P.H. 1983. Multiple antibiotic resistance indexing of Escherichia coli to identify high-risk sources of fecal contamination of foods. Applied and Environmental Microbiology. 46: 165-170.

11 Laxminarayan R., Duse A., Wattal C., Zaidi A.K.M., Wertheim H.F.L., Sumpradit N., Vlieghe E., Hara G.L., Gould I.M., Goossens H., Greko C., So A.D., Bigdeli M., Tomson G., Woodhouse W., Ombaka E., Peralta A.Q., Qamar F.N., Mir F., Kariuki S., Bhutta Z.A., Coates A., Bergstrom R., Wright G.D., Brown E.D. \& Cars O. 2013. Antibiotic resistance-the need for global solutions. Lancet Infectious Diseases. 13: 1057-1098.

12 Liu M., Wu X., Li J., Liu L., Zhang R., Shao D. \& Du X. 2017. The specific anti-biofilm effect of gallic acid on Staphylococcus aureus by regulating the expression of the ica operon. Food Control. 73: 613-618.

13 Magiorakos A.-P., Srinivasan A., Carey R.B., Carmeli Y., Falagas M.E., Giske C.G., Harbarth S., Hindler J.F., Kahlmeter G., Olsson-Liljequist B., Paterson D.L., Rice L.B., Stelling J., Struelens M.J., Vatopoulos A., Weber J.T. \& Monnet D.L. 2012. Multidrug-resistant, extensively drug-resistant and pandrug-resistant bacteria: an international expert proposal for interim standard definitions for acquired resistance. Clinical Microbiology and Infection. 18: 268-281.

14 Martineau F., Lansac N., Me C., Roy P.H., Ouellette M. \& Bergeron M.G. 2000. Correlation between the Resistance Genotype Determined by Multiplex PCR Assays and the Antibiotic Susceptibility Patterns of Staphylococcus aureus and Staphylococcus epidermidis. Antimicrobial Agents and Chemotherapy. 44: 231-238.

15 Mavrogianni V.S., Menzies P.I., Fragkou I.A. \& Fthenakis G.C. 2011. Principles of Mastitis Treatment in Sheep and Goats. Veterinary Clinics of North America: Food Animal Practice. 27: 115-120.

16 Nakagawa S., Taneike I., Mimura D., Iwakura N., Nakayama T., Emura T., Kitatsuji M., Fujimoto A. \& Yamamoto T. 2005. Gene sequences and specific detection for Panton-Valentineleukocidin. Biochemical and Biophysical Research Communications. 328: 995-1002.

17 Ng L.K.I., Martin M.A. \& Mulvey M. 2001. Multiplex PCR for the detection of tetracycline resistant genes. Molecular and Cellular Probes. 15: 209-215.

18 Paterson G.K., Larsen A.R., Robb A., Edwards G.E., Pennycott T.W., Foster G., Mot D., Hermans K., Baert K., Peacock S.J., Parkhill J., Zadoks R.N. \& Holmes M.A. 2012. The newly described mecA homologue, mecALGA251, is present in methicillin-resistant Staphylococcus aureus isolates from a diverse range of host species. Journal of Antimicrobial Chemotherapy. 67: 2809-2813.

19 Pereira C.S., Santos L.M.M., Machado L.S., Melo D.A., Coelho S.M.O., Pereira V.L.A., Souza M.M.S. \& Nascimento E.R. 2021. Proteomics characterization of Staphylococcus spp. From goat mastitis and phenogeno-typical assessment of resistance to beta-lactamics. Pesquisa Veterinária Brasileira. 41: 1-6.

20 Prabhu K., Rao S. \& Rao V. 2011. Inducible clindamycin resistance in Staphylococcus aureus isolated from clinical samples. Journal of Laboratory Physicians. 3:25-27. 
21 Queiroga R.C.R.E., Santos B.M., Gomes A.M.P., Monteiro M.J., Teixeira S.M., Souza E.L., Pereira C.J.D. \& Pintado M.M.E. 2013. Nutritional, textural and sensory properties of Coalho cheese made of goats', cows' milk and their mixture. LWT - Food Science and Technology. 50: 538-544.

22 Sawant A.A., Gillespie B.E. \& Oliver S.P. 2009. Antimicrobial susceptibility of coagulase-negative Staphylococcus species isolated from bovine milk. Veterinary Microbiology. 134: 73-81.

23 Souza V., Martins P.Y.F., Pinto D.S., Fernandes D.R. \& Lima A.R. 2017. Sensibilidade antimicrobiana de Staphylococcus aureus isolados no leite de cabras com mastite subclínica. Comunicado Técnico On-line. 167: 1-7. Available in: < https://www.embrapa.br/busca-de-publicacoes/-/publicacao/1087468/sensibilidad e-antimicrobiana-de-staphylococcusaureus-isolados-no-leite-de-cabras-com-mas tite-subclinica>. [Accessed online in June 2021].

24 Truong-Bolduc Q.C., Dunman P.M., Strahilevitz J., Projan S.J. \& Hooper D.C. 2005. MgrA Is a Multiple Regulator of Two New Efflux Pumps in Staphylococcus aureus. Journal of Bacteriology. 187: 2395-2405.

25 Truong-Bolduc Q.C., Strahilevitz J. \& Hooper D.C. 2006. NorC, a new efflux pump regulated by MgrA of Staphylococcus aureus. Antimicrobial Agents and Chemotherapy. 50: 1104-1107.

26 Truong-Bolduc Q.C., Zhang X. \& Hooper D.C. 2003. Characterization of NorR Protein, a Multifunctional Regulator of norA Expression in Staphylococcus aureus. Journal of Bacteriology. 185: 3127-3138.

27 Zelazny A.M., Ferraro M.J., Glennen A., Hindler J.F., Mann L.M., Munro S., Murray P.R., Reller L.B., Tenover F.C. \& Jorgensen J.H. 2005. Selection of strains for quality assessment of the disk induction method for detection of inducible clindamycin resistance in Staphylococci: a CLSI collaborative study. Journal of Clinical Microbiology. 43: 2613-2615. 